\title{
Pemanfaatan Sampah Organik untuk Pupuk Kompos dan Budidaya Maggot Sebagai Pakan Ternak
}

\author{
Reni Mulyani ${ }^{1}$, Devi Indah Anwar ${ }^{2}$, Neneng Nurbaeti ${ }^{3}$ \\ Universitas Muhammadiyah Sukabumi ${ }^{1,2,3}$ \\ renimulyani@ummi.ac.id ${ }^{1}$, anwardevi32@gmail.com², nngnurbaeti@gmail.com³
}

\begin{abstract}
Organic waste that comes from daily food leftovers in the community has not been used properly, people still put together organic waste and non-organic waste which is then burned, this results in the environment being exposed to carbon dioxide from burning garbage. In Nyalindung Village, many of the people make a living as breeders and farmers, where farmers buy their agricultural crops from Sukabumi City, which is quite far from Nyalindung Village, as well as breeders who buy chicken feed from cities which are quite far and expensive. To reduce organic waste, this community service will conduct training on how to process organic waste into compost so that it can be used by farmers, and the use of organic waste for maggot cultivation so that it can be used by chicken breeders as high protein feed. The target output of this community service is the community, farmers and breeders can make fertilizer and animal feed based on maggot
\end{abstract}

Keywords: waste; organic; maggot; compost.

\begin{abstract}
Abstrak
Sampah organik yang berasal sisa makanan sehari-hari di masyarakat belum dimanfaatkan dengan baik, masyarakat masih mennyatukan sampah organik dan sampah non organik yang kemudian dibakar, hal tersebut mengakibatkan Lingkungan terpapar karbon dioksida dari pembakaran sampah. Di Desa Nyalindung Masyarakatnya banyak berpencaharian sebagai peternak dan petani, Dimana para petani untuk memupuk tanaman pertaniannya membeli dari Kota Sukabumi yang jaraknya cukup jauh dari Desa Nyalindung, begitu pula dengan Peternak membeli pakan ayam dari kota yang jaraknya cukup jauh dan mahal. Untuk mengurangi sampah organik, pada pengabdian Masyarakat ini akan dilakukan pelatihan cara pengolahan sampah organik menjadi pupuk kompos agar bisa dimanfaatkan oleh petani, dan pemanfaatan sampah organik untuk budidaya maggot agar dapat dimanfaatkan oleh para peternak ayam sebagai pakan berprotein tinggi. Target Luaran dari pengabdian masyarakat ini adalah masyarakat, para petani dan peternak dapat membuat pupuk dan pakan ternak berbasis maggot
\end{abstract}

Kata Kunci: sampah; organik; maggot; kompos. 


\section{A. PENDAhuluan}

Desa Nyalindung merupakan salah satu dari 10 desa yang berada di kecamatan Nyalindung Luas wilayah Desa Nyalindung secara keseluruhan adalah seluas $1.150 \mathrm{Ha}$. Desa Nyalindung berada di ketinggian 700900 meter di atas permukaan laut.

Desa Nyalindung kecamatan Nyalindung secara topografi merupakan Dataran, Pegunungan dan perbukitan. Wilayah Desa Nyalindung yang beriklim tropis basah memiliki curah hujan sebesar 2000-3000 mm pertahun. Desa Nyalindung memiliki intensitas curah hujan cukup tinggi sehingga suhu udara rendah, sehingga dapat mendukung kegiatan masyarakat dalam bidang pertanian.

Potensi di bidang pertanian, perkebunan,dan peternakan merupakan potensi unggulan yang terdapat di Desa Nyalindung, Komoditas padi, jagung dan sayuran iklim yang baik serta kemampuan petani dalam bidang pertanian. Selain pertanian masyarakat disana juga mengembangkan peternakan seperti peternakan sapi, kelinci,domba, dan ayam kampung.

Desa Nyalindung merupakan salah satu desa yang terdapat di Ibu Kota Kecamatan Nyalindung sehingga sangat menunjang aktivitas ekonomi di Desa Nyalindung terdapat jalan utama yang merupakan aksesibilitas atau jalur penghubung yaitu menghubungkan antara Kabupaten Sukabumi dan Cianjur yang merupakan jalur penghubung untuk memasarkan hasil pertanian dan peternakan. Saluran air yang cukup memadai dan didukung oleh sumber daya air yang cukup.

Permasalahan yang dihadapi oleh

warga Desa Nyalindung Kecamatan Nyalindung diantaranya adalah: a. Masyarakat Desa Nyalindung mengolah sampah organik yang berasal dari dedaunan kering yang jatuh dan sisa makanan masih dengan cara dibakar sehingga menimbulkan polusi asap dan mengganggu kesegaran udara.

b. Peternak ayam kampung di Desa Nyalindung sebagai mitra produktif kesulitan untuk mengadakan Pakan ternak, Pakan Ternak ayam umumnya menggunakan Pur komersial dan diperoleh dari kota yang jaraknya cukup jauh dari Desa Nyalindung dan Mahal.

c. Petani Didesa Nyalindung sebagai mitra Produktif banyak menggunakan pupuk Kimiawi untuk memupuk tanamannya.

\section{B. PELAKSAAAN DAN METODE}

Solusi untuk mengatasi permasalahan masyarakat, petani, dan peternak di Desa Nyalindung yaitu:

1. Solusi pertama untuk pengelolaan sampah dilakukan edukasi berupa penyuluhan dan pelatihan pengelolaan sampah. Masyarakat, petani dan peternak dilatih bagaimana memilah sampah organik dan mengolahnya menjadi sesuatu yang bermanfaat bagi pertanian dan peternakan, dan juga dibentuk Bank sampah.

2. Solusi kedua, Peternak ayam kampung dilatih untuk membudidayakan maggot dengan media sampah organik untuk pakan ayam yang berprotein tinggi.

3. Solusi ketiga, Petani di latih membuat komposer pupuk organik dari sampah organik dari dedaunan yang jatuh. Pemanfaatan kompos merupakan solusi untuk mengatasi kelangkaan dan kenaikan harga pupuk anorganik yang terus melambung.

Luaran yang akan dihasilkan dari kegiatan tersebut adalah masyarakat dapat 
memilah sampah organik dan nonorganik, terbentuknya bank sampah, tersedianya pupuk kompos untuk pertanian, tersedianya Pakan ternak berprotein tinggi berbasis maggot untuk Peternak Ayam Kampung

Untuk memecahkan persoalan yang dihadapi oleh masyarakat mengenai pengelolaan sampah organik maka akan dilaksanakan:

1. Penyuluhan Pemilahan Sampah

2. Pembentukan Bank Sampah

3. Budidaya Maggot

4. Pembuatan Pupuk Kompos

Secara sederhana, sampah di Indonesia minimal terpilah menjadi dua jenis yaitu sampah anorganik (plastik dan kardus) dan organik (sisa-sisa makanan).

Bank sampah diharapkan bisa mendorong masyarakat untuk melakukan kegiatan pemilahan sampah agar menekan jumlah sampah dan menambah pendapatan masyarakat.

Petani yang berada di Desa Nyalindung dilatih untuk memanfaatkan sampah yang berasal dari dedaunan jatuh untuk dijadikan pupuk kompos. Pengomposan merupakan salah satu metode pengelolaan sampah organik yang bertujuan mengurangi dan mengubah komposisi sampah menjadi produk yang bermanfaat (Suwatanti dkk, 2017). Kompos merupakan salah satu jenis pupuk organik yang sudah ada sejak lama. Proses yang terjadi pada pengomposan yaitu bahan-bahan organik yang sudah mengalami proses pelapukan karena terjadi interaksi antara mikroorganisme atau bakteri pembusuk yang bekerja di dalam bahan organik tersebut. Bahan organik yang dimaksud pada pengertian kompos adalah rumput, jerami, sisa ranting dan dahan, kotoran hewan, bunga yang rontok, air kencing hewan ternak, serta bahan organik lainnya. Semua bahan organik tersebut akan mengalami pelapukan yang diakibatkan oleh mikroorganisme yang tumbuh subur pada lingkungan lembap dan basah.

Pada dasarnya, proses pelapukan ini merupakan proses alamiah yang biasa terjadi di alam. Namun, proses pelapukan secara alami ini berlangsung dalam jangka waktu yang sangat lama, bahkan bisa mencapai puluhan tahun. Untuk mempersingkat proses pelapukan, diperlukan adanya bantuan dari manusia. Jika proses pengomposan dilakukan dengan benar, proses hanya berlangsung selama 1-3 bulan saja, tidak sampai bertahun-tahun.

Penggunaan kompos sangat baik untuk tanah dan tanaman. Kompos dapat menyediakan unsur hara mikro bagi tanaman. Penggunaannya bisa sekaligus menggemburkan tanah yang tandus, meningkatkan porositas, aerasi, dan komposisi mikroorganisme di dalam tanah.

Kompos juga berguna untuk meningkatkan daya ikat tanah terhadap air sehingga dapat menyimpan air tanah lebih lama. Ketersediaan air di dalam tanah dapat mencegah lapisan kering pada tanah. Penggunaan kompos bermanfaat untuk menjaga kesehatan akar serta membuat akar tanaman mudah tumbuh.

Pembuatan kompos dari sampah organik mengacu kepada Mumi Yuniawati, 2012, dengan cara ferrnentasi menggunakan EM4 sebagai aktivator, Bentuk EM4 adalah berupa cairan yang berwarna kecokelatan dan beraroma segar. EM4 sendiri mengandung bakteri fermentasi, mulai dari genus Lactobacillus, jamur fermentasi, bakteri fotosintetik Actinomycetes, bakteri pelarut fosfat, dan juga ragi. Proses ini dilakukan melalui 2 tahap, yaitu tahap persiapan bahan baku yang meliputi persiapan sampah organik dan pembuatan stater EM4 serta tahap pengomposan yaitu bahan baku dicampur dan ditempatkan 
dalam wadah tertutup di ruang gelap agar terjadi proses pengomposan anaerob.

Maggot atau larva dari lalat Black Soldier Fly (BSF) menjadi salah satu organisme potensial untuk dapat dimanfaatkan sebagai agen pengurai limbah organik dan sebagai pakan tambahan bagi ikan dan ternak. Jenis lalat $H$. Illucens menyukai aroma media yang khas tetapi tidak semua media dapat dijadikan sebagai tempat bertelur bagi lalat H.ilucens (Tomberlin et al. 2018). Maggot juga dapat digunakan sebagai pengurai sampah organik yang biasa dihasilkan rumah tangga. Kesempatanuntuk mengurai sampah organik dengan larva BSF sangat menjanjikan karena larva BSF yang dipanen dapat berguna sebagai sumber protein untuk pakan hewan, sehingga dapat dijadikan sebagai pakan alternatif pengganti pakan konvensional (Dortmans et al. 3017).

Harlystiarini (2017) menyatakan bahwa kandungan lemak tepung larva BSF cukup tinggi yakni $27,36 \%$ dibandingkan dengan kandungan lemak tepung pada meat bone meal (MBM) yang hanya sebesar $5,59 \%$. Pada pengabdian ini masyarakat diberikan pelatihan budidaya magot dimana tujuannya adalah mensosialisasikan kepada masyarakat akan pemanfaatan dan pengolahan sampah agar bernilai ekonomis dimana hasilnya dapat digunakan untuk pakan ternak. Budidaya maggot untuk alternatif pakan ayam kampung mengacu kepada penelitian Reni dkk, 2019. Maggot merupakan belatung dari black soldier flys hermetia illucens yang termasuk keluarga lalat. Ukurannya lebih besar dari lalat pada umumnya. Hermetua illucens ini tidak menularkan bakteri, penyakit, bahkan kuman kepada manusia. Maggot menghasilkan larva, nantinya menjadi belatung atau maggot. Limbah organik yang bau, akan dimakan maggot.

\section{HASIL DAN PEMBAHASAN}

Pengabdian masyarakat stimulan yang berlokasi di Tampian Sajid Desa Nyalindung Kecamatan Nyalindung Kabupaten Sukabumi, dilatih untuk dapat memilah sampah. Salah satu langkah utama dalam pengelolaan sampah adalah sorting atau pemilahan. Sampah harus dipilah dan dibuang berdasarkan jenisnya agar pengelolaan sampah lebih mudah. Sampah yang telah dipilah dapat kembali bermanfaat dengan cara menukarnya di Bank Sampah. Tahap pertama yang dilakukan adalah membuat tempat sampah organik dan organik dan diberikan warna yang berbeda serta label, Tahap kedua masyarakat diberikan penyuluhan pemilahan sampah dilaksanakan diruang terbuka dan diikuti oleh RT, RW, Kader posyandu, pengurus karangtaruna serta masyarakat Desa Nyalindung.

Masyarakat diberikan pengetahuan mengenai jenis-jenis sampah, Bahaya sampah bagi kesehatan, praktek cara Pemilahan sampah dibimbing untuk memilah sampah dan memasukan sampah tersebut berdasarkan jenisnya organik dan organik ke tempat sampah. Tahap ketiga masyarakat membagi dua sampah organik yang dimanfaatkan selanjutnya untuk pembuatan kompos dan media budidaya maggot. Sampah anorganik berupa plastik, kaleng dan kertas dibawa ke bank sampah untuk dijual. Jadi kegiatan ini bukan hanya mengurangi jumlah sampah yang dibuang, namun juga akan mendapatkan uang sesuai dengan banyaknya sampah yang ditukar. Sampah-sampah yang telah ditukar di Bank Sampah juga akan didaur ulang, salah satunya dengan menjadi produk-produk kerajinan.

Bank Sampah dibentuk untuk menampung sampah organik dan sampah anorganik. Sampah organik diolah menjadi 
kompos yang dihasilkan diberikan kepada tanamannya, sebelum dilaksanakan pelatihan atau kegiatan pemilahan, pemanfaatan sampah organik menjadi kompos para peserta kegiatan dibagikan masker, handsanitizer dan juga diberikan penyuluhan Adaftasi Kebiasaan Baru, hal ini dilaksanakan karena pengabdian masyarakat berlangsung saat terjadi pandemi covid- 19 . Jadi untuk meminimalkan penyebaran maka peserta kegiatan diberikan alat pelindung diri berupa masker, handsanitizer. Untuk keberlanjutan program, masyarakat yang mengikuti pelatihan dapat menjadi fasilitator dilingkungannya dan diberikan bantuan berupa sumbangan peralatan dan bahan untuk mengolah sampah organik menjadi kompos.

Dalam pengabdian masyarakat stimulan maggot dikembangbiakan dari telur lalat tentara hitam dalam media limbah organik. Maggot yang terbentuk diberikan pada ayam kampung dengan dikombinasikan azolla. Pada penelitian Melta dkk, 2009 bahwa maggot dapat meningkatkan pertumbuhan dan kesehatan ikan. Maggot merupakan salah satu sumber protein hewani tinggi karena mengandung kisaran protein 30-45\% (Akhmad dkk, 2017). Peternak yang berada di Desa Nyalindung dilatih membudidayakan maggot dengan media sampah organik untuk menghasilkan pakan berprotein tinggi.

Program Sosialisasi Budidaya Maggot dilaksanakan selama 1 bulan (Gambar 1). Sosialisasi dibagi menjadi dua kegiatan yaitu penyampaian materi dan praktek budidaya maggot. Materi yang disampaikan tentang pengenalan, siklus hidup, tata cara membudidayakan maggot, keuntungan dalam membudidayakan maggot. Selain itu juga disampaikan media budidaya yaitu sampah organik. Selama kegiatan berlangsung, partisipan aktif mendengarkan dan bertanya pada sesi tanya jawab sehingga dapat terlihat bahwa masyarakat tertarik untuk melakukan budidaya maggot. Praktek meliputi pembangunan dua buah kandang maggot, cara budidaya dan pemberian pakan keternak ayam kapung.
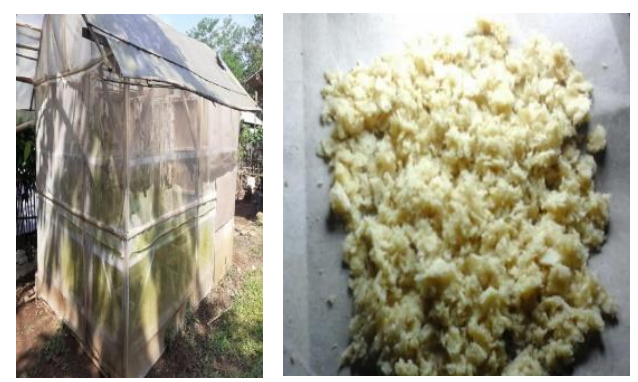

Gambar 1. Budidaya maggot

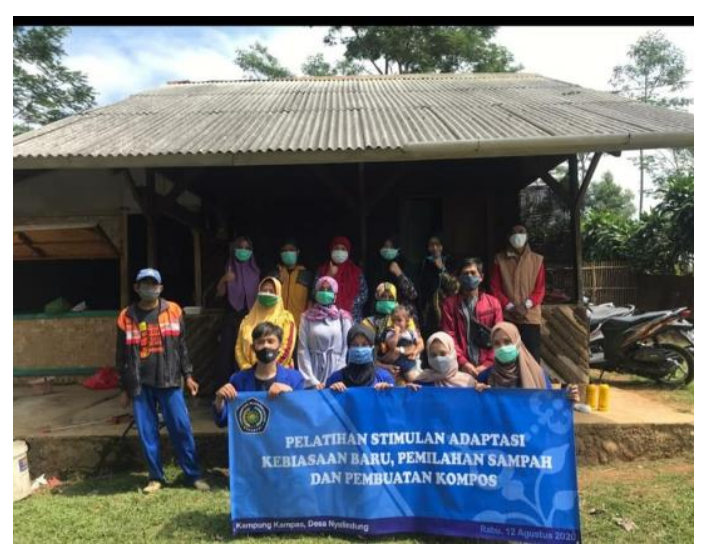

Gambar 2. Peserta Pelatihan Pengabdian Masyarakat Stimulan

Pada pembuatan kompos peserta pelatihan diberikan pengetahuan mengenai bahan dan alat pembuatan kompos, cara pembuatan kompos, proses fermentasi dan pemanfaatannya untuk pupuk tanaman.Adapun peserta pelatihan pemilahan sampah dan pembuatan kompos dapat dilihat pada Gambar 2. 


\section{PENUTUP}

\section{Simpulan}

Sampah yang dihasilkan dapat dikelola dan dipilah sehingga bernilai ekonomis untuk pertanian dan peternakan, dari sampah organik berupa sampah dedaunan masyarakat dapat membuat dan memperoleh pupuk alternatif berupa kompos dan diaplikasikan ke tanaman pertaniannya.Untuk pakan ternak masyarakat dapat memperoleh pakan alternatif yang memiliki kandungan gizi terutama protein yaitu dari maggot. Pemberdayaan masyarakat mengolah sampah dan budidaya maggot memiliki nilai ekonomis untuk petani dan peternak Desa Nyalindung kecamatan Nyalindung Kabupaten Sukabumi.

\section{Saran}

Perlunya perhatian dari pemerintah terhadap pengelolaan pertanian dan peternakan di kecamatan Nyalindung, dan juga diperlukannya pendamping lapangan untuk para petani dan peternak.

\section{Ucapan Terima Kasih}

Terima kasih kepada RISTEK/BRIN yang telah mendanai pengabdian masyarakat melalui hibah PKMs, dan juga kepada Lembaga Penelitian dan Pengabdian Masyarakat Universitas Muhammadiyah Sukabumi.

\section{E. DAFTAR PUSTAKA}

Akhmad Azir, Helmi Harris, dan Rangga Bayu Kusuma, 2017. Produksi dan Kandungan Nutrisi, Ikan. Jurnal Riset Akuakultur. Vol 4 No 2.
Dortmans B, Diener S, Verstappen B, Zurbrügg. 2017. Proses Pengolahan Sampah Organik dengan Black Solier Fly: Panduan Langkah-langkah Lengkap. Octavianti DC. Dübendorf $(\mathrm{CH})$ : Eawag-Swiss Federal Institute of Aquatic Science and Technology.

Harlystiarini. 2017. Pemanfaatan tepung larva black soldier fly (Hermetia illucens) sebagai sumber protein pengganti tepung ikan pada pakan puyuh petelur (Cortunix cortunix japonica). [Tesis]. Bogor (ID): Institut Pertanian Bogor.

Mumi Yuniwati, Frendy lskarima, Adiningsih Padulemba. 2012. Optimasi Kondisi Proses Pembuatan Kompos dari Sampah Organik Dengan Cara Fermentasi Menggunakan EM4. Jurnal Teknologi. Vol 5 No 2 (2012).

Melta Rini Fahmi, Saurin Hem, I Wayan Subamia. 2009. Potensi Maggot untuk Peningkatan Pertumbuhan dan kesehatan Maggot (Chrysomya Megacephala) Menggunakan Komposisi Media Kultur Berbeda. Jurnal Ilmu-ilmu Perikanan dan Budidaya Perairan. Volume 12, Nomor 1.

Mulyadi, Nurhayati. 2019. Uji Proximat Pelet magoot untuk pakan Ikan, Seminar BAPEDA Kota Sukabumi.

Suwatanti, P Widiyaningrum. 2017. Pemanfaatan MOL Limbah Sayur pada Proses Pembuatan Kompos. Jurnal MIPA. 40(1) (2017): 1-6.

Tomberlin JK, Adler PH, Myers HM. 2009. Development of the Black Soldier Fly (Diptera: Strationmyidae) in Relation to Temperature. Environmental Entomol. 38:930-934. 